\title{
Bioactive Compound Contents and Antioxidant Activity of Fermented Lead Tree (Leucaena Leucocephala (Lmk.) De Wit) Seeds
}

\author{
Venty Suryanti ${ }^{1,2, *}$, Soerya Dewi Marliyana ${ }^{1}$, Gracia Lasma Rohana' ${ }^{1}$ Elyna Wahyu Trisnawati ${ }^{1}$, and Widiyanti ${ }^{1}$ \\ 'Department of Chemistry, Faculty of Mathematics and Natural Sciences, Uiversitas Sebelas Maret, Jl. Ir. \\ Sutami 36A Surakarta 57126, Indonesia. \\ ${ }^{2}$ Center for Research and Development of Biotechnology and Biodiversity, Universitas Sebelas Maret, JI. Ir. \\ Sutami 36A Surakarta 57126, Indonesia.
}

*Corresponding author email: venty@mipa.uns.ac.id

Received March 01, 2021; Accepted June 15, 2021 ; Available online November 15, 2021

\begin{abstract}
Leucaena leucocephala (lmk.) de Wit) (leed tree) seeds have been fermented by Indonesian as a traditional food which is called tempeh. The fermentation products of legume seeds are good functional foods, since they contain many bioactive compounds. The objective of this study was to determine the bioactive compound contents of fermented lead tree seed, such as total phenolic, ascorbic acid, $\beta$-carotene and $\alpha$-tocopherol. Antioxidant activity testing was carried out using the thiobarbituric acid reactive substances (TBARS) method. Analysis of total phenolics, ascorbic acid, $\beta$-carotene and $\alpha$ tocopherol were carried out using the folin-ciocalteu method, iodine titration, spectrophotometry and iron (III) chloridethiocyanate, respectively. Rhizopus oligosporus was used to ferment lead tree seeds for $0,1,2,3$ and 4 days. Fermented leed tree seed powder was extracted with petroleum ether followed by ethanol. In comparison to unfermented leed tree seed powder, the $\beta$-carotene and $\alpha$-tocopherol of the fermented seed powder increased. The greatest enhancement of $\beta$-carotene and $\alpha$-tocopherol contents were observed at day 2 of fermentation. The highest antioxidant activities of fermented leed tree seeds were also obained at day 2 of fermentation with $55.55 \pm 4.59$ and $74.46 \pm 3.49 \%$ inhibition in petroleum ether and ethanol extracts, respectively. The results show that lead tree seed tempeh has high antioxidant activity due to the bioactive compounds contains, such as phenolics, $\beta$-carotene and $\alpha$-tocopherol. Therefore, leed tree seed tempeh could be used for possible commercial production of functional food to alleviate oxidative stress.
\end{abstract}

Keywords: antioxidant, $\beta$-carotene, Leucaena leucocephala, tempeh, $\alpha$-tocopherol

\section{INTRODUCTION}

Fermentation has been applied to enhance the nutritional and antioxidant properties of cereal and legume seeds (Brou et al., 2009; Jirapa, Jarae, Phanee, \& Jirasak, 2016; Megat, Azrina, \& Norhaizan, 2016; Nazarni, Purnama, Umar, \& Eni, 2016; Phattayakorn, Pajanyor, Wongtecha, Prommakool, \& Saveboworn, 2016). Microbial fermentation of cereals and legumes by fungi, yeasts, or bacteria has an impact on the releasing or increasing phenolic acids, flavonoids, saponins, phytosterols, vitamin A and E (tocopherols). The changes of protein and phenolic grains composition during fermentation are influenced by the metabolic activities of the specific starter used, cultivation conditions, and the effect of proteinases or other enzymes involved in phenolics and protein metabolism (Verni, Verardo, \& Rizzello, 2019). Several studies have been reported about diversity of microorganisms used in fermented foods, such as Rhizopus oligosporus, Rhizopus microspores, Bacillus sp., Lactobacillus sp., Aspergillus sp., Mucor sp.,
Actinomucor sp., Bifidobacterium sp. (Rashad, Mahmoud, Abdou, \& Nooman, 2011; Verni et al., 2019).

Fermentation process of soybean produced a significant increase in the levels of complex biochemical metabolism, mainly phenolic compounds, protein and vitamins. Therefore, it affects the beneficial biological effects associated with these bioactive components (Amadou, Yong-Hui, Sun, \& Guo-Wei, 2009; Bavia et al., 2012; Duenas et al., 2012; Bei, Wu, \& Chen, 2020). Koili is a fermentation product of black beans by Aspergillus sp. and Rhizopus sp., which is known for their great nutritious properties consist of vitamin E, carotenoids, saponins, isoflavones and anthocyanins. The metabolic activities rises phenolics and anthocyanins contents which causes in increasing antioxidant activities (Kumar et al., 2021). In Indonesia, the fermentation product of soybean by Rhizopus sp. is called as tempeh. Apart from soybean-based tempeh, a variety of legumes and seeds, such as barley, chick pea, cowpea, ground bean, horse bean, lima bean, pea, oats, sorghum, 
wheat, corn, rice, lentils have been used as raw materials for making tempeh (Astuti, Meliala, Dalais, \& Wahlqvist, 2000; Vital et al., 2018).

Leucaena leucocephala (lead tree) is a legume and belongs to Fabaceae family, sub family Mimosoideae (Muhammad et al., 2019). Lead tree seeds contain lipids, protein and carbohydrates and are consumed by humans in processed and unprocessed forms. Seed and leaf of $L$. leucocephala contain the same compounds, such as apigenin, formic acid, caffeic acid, isorhamnetin, luteolin, keampferol, and quercetin. However, the compounds in seed are higher than the compounds in leaf (Zarina, Ruzaidi, Sam, \& Al Bakri, 2019).

To develop health food ingredients, we have previously performed germination on L. Leucocephala and investigated the antioxidant activity of the sprouts (Suryanti, Marliyana, \& Putri, 2016). Germination for 4 days affected the greatest enhancement in antioxidant activity by 2.78 fold and affected a significant increased in total phenolics content by 7.29 , $\beta$-carotene by 3.27 , ascorbic acid by 3.81 and $\alpha$-tocopherol by 4.58 fold, respect to imbibed seeds. The findings suggested that $L$. leucocephala sprouts could be considered as a source of natural antioxidant.

In the present study, we performed fermentation on lead tree seeds using $R$. oligosporus and evaluated bioactive compounds such as total phenolics, $\beta$ carotene, ascorbic acid and $\alpha$-tocopherol contents during fermentation periods. We also investigated the correlation between the antioxidant activity of lead tree tempeh and their bioactive contents.

\section{EXPERIMENTAL SECTION Materials}

Lead tree seeds were supplied from local market. Seeds were cleaned and stored in darkness in polyethylene containers at $4^{\circ} \mathrm{C}$. All the chemicals used were of analytical grade, purchased from Merck Chemical Company (Merck, Germany).

\section{Microorganism}

$R$. oligosporus was obtained from Inter University Centre of Food and Nutrition (Pusat Antar Universitas), Universitas Gadjah Mada, Indonesia. Yeast was maintained on potato dextrose agar (PDA) and stored at $4^{\circ} \mathrm{C}$ and sub-cultured monthly. For inoculums preparation, the culture was streaked onto PDA slant and incubated at $30^{\circ} \mathrm{C}$ for $48 \mathrm{~h}$. Sterilized water $(9 \mathrm{~mL})$ was added to PDA slant for growing broth culture.

The media were made from rice grains $(50 \mathrm{~g})$ and water $(50 \mathrm{~mL})$. It was autoclaved at $121^{\circ} \mathrm{C}, 1 \mathrm{~atm}$ for 15 mins for making porridge. After cooling down to room temperature, It was inoculated with broth culture of $R$. oligosporus $(1 \mathrm{~mL})$ and incubated at $30^{\circ} \mathrm{C}$ on a shaker at $200 \mathrm{rpm}$ for $48 \mathrm{~h}$. After ovendried at $50^{\circ} \mathrm{C}$ for $6 \mathrm{~h}$, cultured rice flour was pulverized using blender to a fine powder. The obtained powder culture was used for inoculation of lead tree seeds. The powder culture was stored in glass containers at $4^{\circ} \mathrm{C}$ for further use.

\section{Fermentation and Freeze-Dried}

Lead tree seeds $(400 \mathrm{~g})$ were boiled in $2 \mathrm{~L}$ water for 60 minutes, cooled and cleaned to remove the hulls. The de-hulled and cleaned cotyledons were soaked in water for 2 days by changing the water two times. The water was discarded and the cotyledons were washed several times, and drained. The clean cotyledons were placed on aluminium foil and then autoclaved at $121^{\circ} \mathrm{C}$ for $15 \mathrm{~min}$. The cotyledons were cooled down to room temperature and $80 \mathrm{~g}$ of cotyledons were placed in a petri dish and then inoculated with powder culture of $R$. oligosporus $(1 \%$ $w / w)$. They were then incubated at $30^{\circ} \mathrm{C}$ for different times of fermentation including $0,1,2,3$ and 4 days. Fresh tempeh were freeze-dried, milled, and passed through a sieve of $0.5 \mathrm{~mm}$. The tempeh flour was stored in glass containers at $4^{\circ} \mathrm{C}$ for further analysis.

\section{Preparation of Extracts}

The powdered tempeh $(20 \mathrm{~g})$ was transferred into a Soxhlet apparatus and extracted in the Soxhlet extractor using $300 \mathrm{~mL}$ petroleum ether for $6 \mathrm{~h}$. The residue was sequentially macerated with $100 \mathrm{~mL}$ ethanol and allowed to stand for $24 \mathrm{~h}$. The samples were filtered with filter paper and the residue was further macerated twice under the same conditions. The collected filtrates were combined and concentrated using a rotary evaporator (Bibby RE 200) under reduced pressure. The extracts were were kept in dry clean black glass bottle at $4^{\circ} \mathrm{C}$ for further analysis.

\section{Determination of Total Phenolics Content}

Total phenolics content was determined using the Folin-Ciocalteu method (Baba, \& Malik, 2015). A calibration curve of chlorogenic acid was prepared and the results were expressed as chlorogenic acid equivalents ( $\mathrm{mg}$ CAE/g dry matter). In this method, 0.1 $\mathrm{g}$ of extract, Folin-Ciocalteu's reagent $(1 \mathrm{~mL})$ and saturated $\mathrm{Na}_{2} \mathrm{CO}_{3}$ solution $(2 \mathrm{~mL}$ ) were added into a test tube. A control sample was prepared at the same time using distilled water $(1 \mathrm{~mL})$, Folin-Ciocalteu's reagent $(1 \mathrm{~mL})$ and saturated $\mathrm{Na}_{2} \mathrm{CO}_{3}$ solution $(2 \mathrm{~mL})$. Ingredients in test tubes were well mixed using vortex and left in a dark place for 2 hours. Absorbance was measured at $760 \mathrm{~nm}$ using an UV mini 1240 spectrophotometer (Shimadzu, France).

\section{Determination of $\beta$-Carotene}

$\beta$-Carotene content of petroleum and ethanol extracts were measured according to Jaramillo et al. (2018) with some modification. As much as $0.1 \mathrm{~g}$ of extract was weighed and dissolved in $5 \mathrm{ml}$ of petroleum eter:acetone $=1: 1$, homogenized in a homogenizer at $1000 \mathrm{rpm}$ for $5 \mathrm{mins}$. The supernatant was taken and measured the absorbance at $450 \mathrm{~nm}$. $\beta$-Carotene was used as a standard for calibration curve. 


\section{Determination of Ascorbic Acid}

Ascorbic acid concentration was measured by redox titration using iodine solution (Ismail \& Hussain, 2014). $0.1 \mathrm{~g}$ of extract was dissolved in $100 \mathrm{~mL}$ of distilled water. $50 \mathrm{~mL}$ aliquot of the sample solution was pipetted into a $250 \mathrm{~mL}$ conical flask and added 2 $\mathrm{mL}$ of $1 \%$ starch indicator solution $10.5 \mathrm{~g}$ of soluble starch and $50 \mathrm{~mL}$ of near boiling water were stirred to dissolve and cooled before using). The sample was titrated with $0.005 \mathrm{M}$ iodine solution $(2 \mathrm{~g}$ of potassium iodide and $1.3 \mathrm{~g}$ of iodine were dissolved in $1 \mathrm{~L}$ of distilled water). The endpoint of the titration was identified as the first permanent trace of a dark blueblack colour due to the starch-iodine complex.

\section{Determination of $\alpha$-Tocopherol}

$\alpha$-Tocopherol was evaluated according to Emmerie-Engel reaction (AOAC, 2019). $0.5 \mathrm{mg}$ of extract in $1 \mathrm{ml}$ of ethanol, $3.5 \mathrm{~mL}$ of tween $80,3.5 \mathrm{ml}$ of $0.2 \% 2,2^{\prime}$-bipyridine in ethanol were placed in a 4 -ml glass test tube and were thoroughly mixed. 0.5 $\mathrm{ml}$ of $0.02 \% \mathrm{M} \mathrm{FeCl}_{3}$ solution in ethanol was added, followed by mixing with a vortex mixer. After 10 mins, $0.2 \mathrm{ml}$ of $0.001 \mathrm{M} \mathrm{H}_{2} \mathrm{PO}_{4}$ solution in ethanol was added and the contents of the tubes were again thoroughly mixed. Standards of D- $\alpha$-tocopherol were prepared at the same time. The absorbance of the solutions was determined at $520 \mathrm{~nm}$ using a Gilford model 240 spectrophotometer.

\section{Determination of Thiobarbituric Acid Reactive Substances (TBARS)}

The test was conducted using thiobarbituric acid reactive substances (TBARS) assay (Leon and Borges, 2020). Petroleum and ethanol tempeh extracts (at 50, 100 and $200 \mathrm{mg} / \mathrm{L}$ concentration) were added to 10 $\mathrm{mL}$ of soybean oil. The reaction mixture was then kept in the oven at $170^{\circ} \mathrm{C}$ for 15 mins. Sample solution $(1.0 \mathrm{~mL})$ was added to the $3.0 \mathrm{~mL}$ of 2 -thiobarbituric acid (TBA) solution (solution of $0.375 \mathrm{~g}$ 2thiobarbituric acid and $15 \mathrm{~g}$ of trichloroacetic acid (TCA) in $1.5 \mathrm{~mL}$ of $0.25 \mathrm{M} \mathrm{HCl}$ ) and the mixture was then made up to $100 \mathrm{~mL}$ with distilled water. The resulting mixture was vigorously mixed and placed in a boiling water bath for 15 mins. After cooling, it was then centrifuged at $4000 \mathrm{rpm}$ for 5 mins. Absorbance of the supernatant was measured at $530 \mathrm{~nm}$. TBA method described antioxidant activity by percent inhibition:

$$
\% \text { Inhibition }=\frac{\text { Abs of control }- \text { Abs of sample }}{\text { Abs of control }} \times 100
$$

Butylated hydroxytolvene (BHT) was used as a standard and the unfermented seed extract was used as a control.

\section{Statistical Analysis}

Experimental results were performed in triplicate and the data are expressed as means \pm standar deviation. The results were compared by one-way
Analysis of variance ANOVA. A difference was considered statistically significant if $p \leq 0.05$.

\section{Gas Chromatography-Mass Spectroscopy (GC-MS)}

The ethanol extract of BR-NI and BR-200 were analyzed by Shimadzu QP2010S GC-MS. The GC-MS was run using El 70 Ev ionizing type, Rtx 5 Ms column type having diameter of $0.25 \mathrm{~mm}$ and column length of $30 \mathrm{~m}$, injector temperature of $300^{\circ} \mathrm{C}$, column temperature of $70^{\circ} \mathrm{C}$, split less injection method, detector temperature of $300^{\circ} \mathrm{C}$ and carrier gas $\mathrm{He}$ of $13.7 \mathrm{kPa}$.

\section{RESULTS AND DISCUSSION}

The powdered tempeh from 0 to 4 days at $24 \mathrm{~h}$ intervals were taken, identified hereafter as LTO, LT1, LT2, LT3 and LT4, respectively. The duration of this fermentation period was based on the laboratory observation, since lead tree seed tempeh was over fermented in longer periods. The complete fermentation of seed was reached during the approximately 2 days process and mycelium spread among the interstice of lead tree seeds (Figure 1). As a result, the 2 days fermented lead tree seeds was softer, white in colour and had a compact form. After 2 days, the sensory profiles (such as color and odor) of fermented lead tree seeds were developed, because mycelium was over grown. At 3 days fermentation, the fermented lead tree seed was light brown in colour, mushy, slimy and smells bad.

No single solvent may be reliable to extract all the bioactive compounds from samples because of its variation in solubility and polarity (Dai and Mumper, 2010; Zia et al., 2020). In the current study, the samples were extracted with petroleum ether and sequentially with ethanol. Using different polarity of solvents, it was expected there would be different types of bioactive compounds present in the extracts.

The petroleum ether extract showed the presence of $\beta$-carotene and $\alpha$-tocopherol and the absence of phenolic compounds and ascorbic acid (Table 1). Chlorogenic acid was used for establishing the standard curve $(0-100 \mathrm{mg} / \mathrm{L}, Y=0.0083 x+0.0465$, $R^{2}=0.9888$ ) for phenolic compounds evaluation. $D-\alpha-$ tocopherol was used to obtaine the standard curve (0$\left.5 \mu \mathrm{g} / \mathrm{L}, \quad Y=0.1207 x+0.9915, R^{2}=0.9915\right)$ for $\alpha$ tocopherol calculation. The deviation standard values are less than $10 \%$ of means value which are acceptable. The ethanol extract show the presence of phenolic compounds and the absence of $\beta$-carotene, $\alpha$-tocopherol and ascorbic acid. Murphy (1982) observed that tempeh preparation which are grain soaking, de-hulling and cooking can result in loss of soluble substances, such as minerals, sugar and water soluble vitamins, from whole grains. Heat treatment in the cooking process causes changes in the nutrition and texture of the food (Liu et al., 2020). Similar result was obtained in this study, ascorbic acid was present at $78.10 \pm 5.41(\mathrm{mg} / 100 \mathrm{~g})$ in whole grains $L T$, 


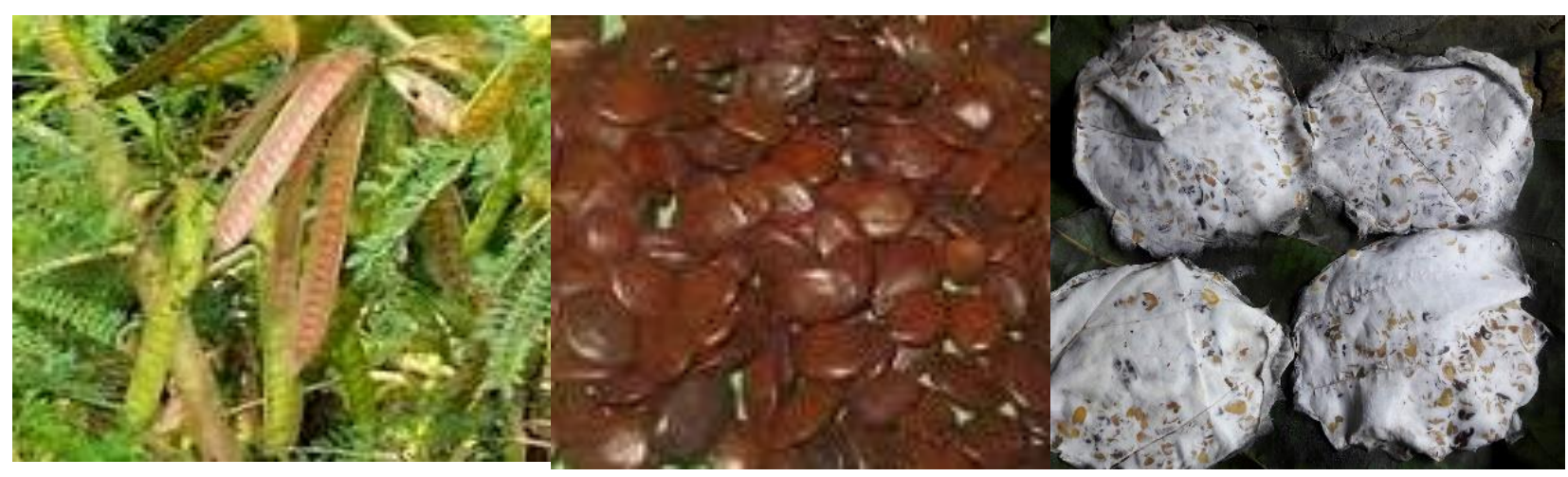

Figure 1. L. leucocephala tree (left), seeds (middle) and tempeh (right).

while it was not found in both unfermented seeds extracts LTO. Although it was insignificant, tempeh preparation reduced the $\beta$-carotene and phenolic compounds contents and increased the $\alpha$-tocopherol content from whole grains LT.

The petroleum ether extract showed the presence of $\beta$-carotene and $\alpha$-tocopherol and the absence of phenolic compounds and ascorbic acid (Table 1). Chlorogenic acid was used for establishing the standard curve $(0-100 \mathrm{mg} / \mathrm{L}, Y=0.0083 x+0.0465$, $R^{2}=0.9888$ ) for phenolic compounds evaluation. D- $\alpha$ tocopherol was used to obtaine the standard curve (0$\left.5 \mu \mathrm{g} / \mathrm{L}, \quad Y=0.1207 x+0.9915, R^{2}=0.9915\right)$ for $\alpha$ tocopherol calculation. The deviation standard values are less than $10 \%$ of means value which are acceptable. The ethanol extract show the presence of phenolic compounds and the absence of $\beta$-carotene, $\alpha$-tocopherol and ascorbic acid. Murphy (1982) observed that tempeh preparation which are grain soaking, de-hulling and cooking can result in loss of soluble substances, such as minerals, sugar and water soluble vitamins, from whole grains. Heat treatment in the cooking process causes changes in the nutrition and texture of the food (Liu et al., 2020). Similar result was obtained in this study, ascorbic acid was present at $78.10 \pm 5.41(\mathrm{mg} / 100 \mathrm{~g})$ in whole grains $L T$, while it was not found in both unfermented seeds extracts LTO. Although it was insignificant, tempeh preparation reduced the $\beta$-carotene and phenolic compounds contents and increased the $\alpha$-tocopherol content from whole grains LT.

The $\beta$-Carotene, $\alpha$-tocopherol and phenolics contents increased to reach their maximum on the second day after fermentation and thereafter an insignificant decrease was observed ( $p>0.05)$. The ethanol extract of LT2 showed a total phenolic content of $46.99 \pm 1.53 \mathrm{mg} \mathrm{CAE} / 100 \mathrm{~g} \mathrm{dw}$ (dried weight) and the petroleum ether extract of LT2 exhibited $\beta$-carotene and $\alpha$-tocopherol contents of $269.18 \pm 10.82$ and $488.64 \pm 11.37 \mathrm{mg} / 100 \mathrm{~g} \mathrm{dw}$, respectively. $\beta$-Carotene, $\alpha$-tocopherol and total phenolic compounds in LT2 increased by $3.77,10.51$ and $4.31 \%$, respectively, compare to the cooked unfermented seeds LTO. Statistical analysis revealed that $\alpha$-tocopherol content of LT2 was significantly higher from those of LT, LTO and LT1 $(p<0.05)$ (Table $1)$. However, although they were an increased in the $\beta$-carotene and phenolics contents of LT2 respect to the cooked unfermented seeds LTO, they were not significantly different from those of LTO and LT1.

Phenolics are usually found in conjugated forms through hydroxyl groups with sugar and glycosides in plant materials (Metsa"muuronen, \& Sire'n, 2019; Bei et al., 2020). Phenolics compounds possess antioxidant activities (Suryanti, Kusumaningsih, Marliyana, Setyono and Trisnawati, 2020). During fermentation, several enzymes are produced, such as $\alpha$-amylase, $\beta$-glycosidase and xylanase, and catalyse the release of the phenolics from the lead tree seeds substrate (Oliveira, Cipolatti, Furlong, \& Soares, 2012; Leite, Silva, Salgado, \& Belo, 2019) evidenced by the gradual increase observed for 2 days. The decrease in the $\beta$-carotene, $\alpha$-tocopherol and phenolics contents after 2 days fermentation probably resulted from degradation of those compounds. These results are comparable to previous reports which indicated that antioxidant compounds increases with fermentation duration and decrease after certain period of time because of degradation (Oliveira et al., 2012; Leite et al., 2019).

In this present study, the thiobarbituric acid reactive substances (TBARS) assay was used to determine the antioxidant activity of the extracts. Table 2 shows antioxidant activity of lead tree seeds during fermentation period. Although it was not significantly different $(p>0.05)$, the antioxidant activity of LTO was lower than that of LT. Possibly, because processes used in tempeh preparation such as heating of the seeds may degrade certain antioxidative phytochemicals, resulting in the decrease of antioxidant activity. During fermentation, the antioxidant activity increased to reach its maximum on the second day and thereafter a slight decrease was observed. 
Table 1. $\beta$-Carotene, $\alpha$-tocopherol and total phenolic contents in the tempeh extracts during fermentation period

\begin{tabular}{cccc}
\hline \multirow{2}{*}{ Samples } & \multicolumn{2}{c}{ Petroleum Ether Extract } & Ethanol Extract \\
\cline { 2 - 4 } & $\begin{array}{c}\beta \text {-Carotene } \\
(\mathrm{mg} / 100 \mathrm{~g} \mathrm{dw})\end{array}$ & $\begin{array}{c}\alpha \text {-Tocopherol } \\
(\mathrm{mg} / 100 \mathrm{~g} \mathrm{dw})\end{array}$ & $\begin{array}{c}\text { Total Phenolics } \\
(\mathrm{mg} \mathrm{CAE} / 100 \mathrm{~g} \mathrm{dw})\end{array}$ \\
\hline LT (raw seeds) & $262.71 \pm 3.26$ & $387.72 \pm 17.33$ & $48.84 \pm 0.73$ \\
LT0 (day 0) & $259.39 \pm 16.66$ & $442.16 \pm 19.96$ & $45.05 \pm 0.53$ \\
LT1 (day 1) & $262.97 \pm 20.47$ & $460.48 \pm 20.01$ & $46.55 \pm 1.46$ \\
LT2 (day 2) & $269.18 \pm 10.82$ & $488.64 \pm 11.37$ & $46.99 \pm 1.53$ \\
LT3 (day 3) & $264.01 \pm 17.93$ & $467.75 \pm 7.34$ & $45.86 \pm 1.80$ \\
LT4 (day 4) & $263.35 \pm 17.58$ & $442.66 \pm 31.34$ & $45.09 \pm 5.86$ \\
\hline
\end{tabular}

Table 2. Antioxidant activity of tempeh extracts at different fermentation time determined by TBARS assay

\begin{tabular}{|c|c|c|c|c|c|c|}
\hline \multirow{3}{*}{ Sample } & \multicolumn{6}{|c|}{ Antioxidant Activity (\% inhibition) } \\
\hline & \multicolumn{3}{|c|}{ Petroleum Ether Extract } & \multicolumn{3}{|c|}{ Ethanol Extract } \\
\hline & $50 \mathrm{mg} / \mathrm{L}$ & $100 \mathrm{mg} / \mathrm{L}$ & $200 \mathrm{mg} / \mathrm{L}$ & $50 \mathrm{mg} / \mathrm{L}$ & $100 \mathrm{mg} / \mathrm{L}$ & $200 \mathrm{mg} / \mathrm{L}$ \\
\hline $\begin{array}{c}\mathrm{LT} \\
\text { aw seeds) }\end{array}$ & $21.05 \pm 6.11$ & $33.90 \pm 9.52$ & $49.47 \pm 1.94$ & $31.66 \pm 3.78$ & $40.08 \pm 7.61$ & $54.34 \pm 2.50$ \\
\hline LTO (day 0) & $19.68 \pm 2.44$ & $33.76 \pm 2.07$ & $48.40 \pm 3.55$ & $33.39 \pm 5.73$ & $33.30 \pm 5.73$ & $53.19 \pm 2.87$ \\
\hline LT1 (day 1) & $25.44 \pm 3.86$ & $35.49 \pm 3$ & $50.67 \pm 2$ & 37.43 & $3 \pm 3.89$ & 4.93 \\
\hline LT2 lo & $26.79 \pm 4.96$ & 40.3 & 55.5 & $45.79 \pm$ & 45. & \pm 3.49 \\
\hline & & & & & & \\
\hline LT4 (day 4) & $24.66 \pm 8.46$ & $37.15 \pm 4.75$ & $51.01 \pm 4.01$ & $42.07 \pm 4.78$ & $42.07 \pm 4.78$ & $72.32 \pm 3.56$ \\
\hline
\end{tabular}

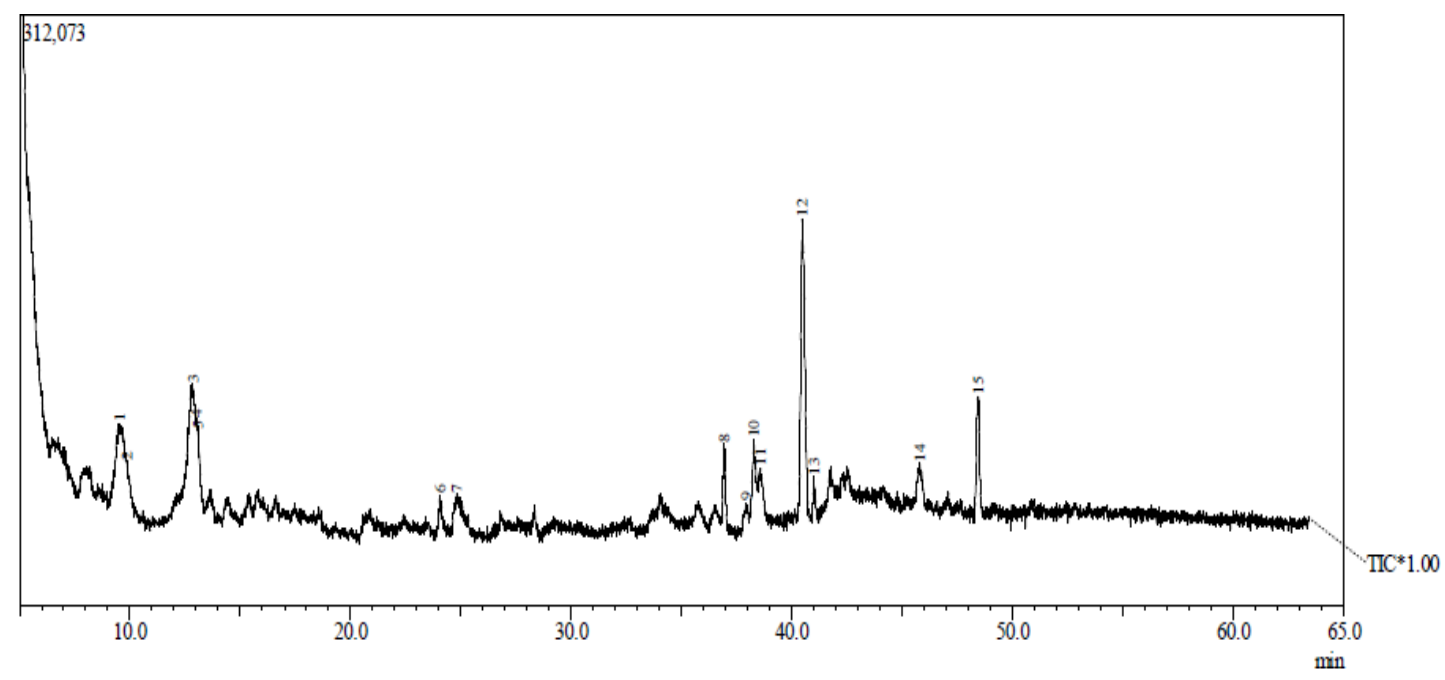

Figure 1. GC Spectrum of ethanol tempeh extract.

Table 3. Identified compounds of ethanol tempeh extract by GC-MS analysis.

\begin{tabular}{lllll}
\hline Peak number & $\begin{array}{l}\text { Retardation time } \\
\text { (mins) }\end{array}$ & $\%$ area & Molecule formula & Compound \\
\hline 8 & 36.933 & 4.12 & $\mathrm{C}_{9} \mathrm{H}_{12} \mathrm{O}_{2}$ & nonanoic acid \\
12 & 40.465 & 12.71 & $\mathrm{C}_{18} \mathrm{H}_{32} \mathrm{O}_{2}$ & 9,12 -octadecanoic acid \\
\hline
\end{tabular}

At $200 \mathrm{mg} / \mathrm{L}$ concentration of extracts, the antioxidant activities of petroleum ether and ethanol extracts were $55.55 \pm 4.59$ and $74.46 \pm 3.49 \%$ inhibition, respectively. In this case, an increase of 14.77 and $39.99 \%$ of antioxidant activity were observed in petroleum ether and ethanol extracts, respectively. Both petroleum ether and ethanol extracts exposed similar results that the highest antioxidant activities of tempeh were achieved after being fermented for 2 days. Antioxidant activities of LT2 in petroleum ether extract was significantly different from LTO and LT1 $(p<0.05)$. Similarly, antioxidant activity of LT2 in ethanol extract was also significantly different from LTO and LT1 $(p<0.05)$. Although it was 
insignificantly different $(p>0.05)$, the antioxidant activity of LT3 was lower than that of LT2. Further decrease in the antioxidant activity of tempeh was observed at 4 days fermentation. The degradation of antioxidant compounds in LT3 and LT4 may occurred, following in the decrease of antioxidant activity.

Overall, the inhibition capacity percentage of the polar fraction of ethanol extract was higher than petroleum ether one with less polar fraction, which might be due to the difference in solvents polarity and consequently the type of extracted compounds. There is significant difference between petroleum ether and ethanol extracts $(p<0.05)$. In this study, we showed that antioxidant activity of tempeh extracts were dependent on the solvent.

Antioxidant activities of standard synthetic antioxidant Butylated hydroxytolvene (BHT) were $73.17 \pm 1.66,86.02 \pm 0.77$ and $92.27 \pm 0.86$ at concentration of 50,100 and $200 \mathrm{mg} / \mathrm{L}$, respectively. Antioxidant activity of the ethanol extract at concentration of $200 \mathrm{mg} / \mathrm{L}$ at LT2 was equal to the antioxidant activity of the positive control Butylated hydroxytolvene $(\mathrm{BHT})$ at concentration of $50 \mathrm{mg} / \mathrm{L}$ $(p<0.05)$.

The ethanol extract chemical composition was further investigated by GC-MS analysis. Although the GC spectrum revealed 15 compounds, only 2 compounds were able to identify based on their similarity index of Mass-Spectroscopy library (Figure 1). They are identified as nonanoic acid and 9,12octadecanoic acid (Table 3). The polyunsaturated fatty acid, namely 9,12-octadecanoic acid, may give a significant contribution in antioxidant activities of ethanol extract. Although there is no evidence yet that 9,12-octadecanoic acid has an antioxidant activity, several polyunsaturated fatty acids have been reported to have antioxidant activities. Richard et al. (2008) provided cellular evidence for the antioxidant actions of polyunsaturated fatty acids, namely eicosapentaenoic acid. Ambrozova, Pekarova, \& Lojek (2010) reported that omega-3 (alpha-linolenic, docosahexaenoic, eicosapentaenoic) and omega-6 (arachidonic, linoleic) have antioxidant activities by inhibiting reactive oxygen species (ROS) and reactive nitrogen species (RNS) formation.

The variety antioxidant activity of samples can be ascribed on the type and polarity of the extracting solvent, the isolation procedures, type and purity of active compounds and the test system (Altemimi, Lakhssassi, Baharlouei, Watson, \& Lightfoot, 2017; Tzanova, Atanasov, Yaneva, Ivanova, \& Dinev, 2020, Leite et al., 2019). The results showed a significant different in the antioxidant activity of lead tree seeds after fermentation in petroleum ether and ethanol extracts. Additionally, increase in antioxidant activity was found to be significantly dependent on the applied solvents. This might be due to difference in solvent polarity and consequently type of the extracted compounds.

\section{CONCLUSIONS}

Fermentation of lead tree seeds by $R$. oligosporus for 2 days exhibited the highest bioactive compound contents and antioxidant activity. In respect to the cooked unfermented seeds, $\beta$-carotene, $\alpha$-tocopherol and total phenolic compounds contents increased by $3.77,10.51$ and $4.31 \%$, respectively. The results suggested that lead tree seeds tempeh obtained from day 2 of fermentation could be used for possible commercial production of functional foods.

\section{ACKNOWLEDGEMENT}

Financial support from Sebelas Maret University through Penerimaan Negara Bukan Pajak (PNBP) funding is greatly appreciated.

\section{REFERENCES}

A.O.A.C. (2019). In AOAC International (Ed.), Official methods of analysis (27 $7^{\text {st }}$ Ed.) Gaithersburg, Maryland, USA.

Altemimi, A., Lakhssassi, N., Baharlovei, A., Watson, D. G., \& Lightfoot, D. A. (2017). Phytochemicals: extraction, isolation, and identification of bioactive compounds from plant extracts. Plants, 6(4): 42. doi:10.3390/plants6040042.

Amadou, I., Yong-Hui, S., Sun, J., \& Guo-Wei, L. (2009). Fermented soybean product: some methods, antioxidants compound extraction and their scavenging activity. Asian Journal of Biochemistry, 4(3), 68-76. DOI: 10.3923/ajb.2009.68.76.

Ambrozova, G., Pekarova, M., \& Lojek, A. (2010). Effect of polyunsaturated fatty acids on the reactive oxygen and nitrogen species production by raw 264.7 macrophages. European Journal of Nutrition, 49(3):133-9.

Astuti, M., Meliala, A., Dalais, F.S., \& Wahlqvist, M. L. (2000). Review article tempe, a nutritious and healthy food from Indonesia. Asia Pacific Journal of Clinical Nutrition, 9(4), 322-325. https://doi.org/10.1046/j.14406047.2000.00176.x.

Baba, S. A., \& Malik, S. A. (2015). Determination of total phenolic and flavonoid content, antimicrobialand antioxidant activity of a root extract of Arisaema jacquemontii Blume. Journal of Taibah University for Science, 9, 449-454.

Bavia, A. C. F., da Silva, C. E., Ferreira, M. P., Leite, R. S., Mandarino, J. M. G., \& Carrao-Panizzi, M. C. (2012). Chemical composition of tempeh from soybean cultivars specially developed for human consumption. Ciência Tecnologia de Alimentos, Campinas, 32(3), 613-620. https://doi.org/10.1590/S0101 20612012005000085.

Bei, Q., Wu, Z., \& Chen, G. (2020). Dynamic changes in the phenolic composition and antioxidant activity of oats during simultaneous hydrolysis 
and fermentation. Food Chemistry, 305, 125269.

10.1016/i.foodchem.2019.125269.

Brou, K., Kouadio, E. J. P., Due, E. A., Kouame, S. K., Tano, K., \& Dago, G. (2009). Effects of processing method and blend on some physicochemical properties and digestibility of flours made from selected cereals and legumes. International Journal of Biological and Chemical Sciences, $3(5), \quad$ 1151-1160. doi: 10.4314/iibcs.v3i5.51093.

Dai, J., \& Mumper, R. J. (2010). Plant phenolics: extraction, analysis and their antioxidant and anticancer properties. Molecules, 15, 73137352. doi: $10.3390 /$ molecules 15107313 .

De Leon, J. A. D., \& Borges, C. R. (2020). Evaluation of oxidative stress in biological samples using the thiobarbituric acid reactive substances assay. Journal of Visualized Experiments, 12(159). doi: 10.3791/61122.

Duenas, M., Hernandez, T., Robredo, S., Lamparski, G., Estrella, I., \& Munoz, R. (2012). Bioactive phenolic compounds of soybean (Glycine max cv. Merit): modifications by different microbiological fermentations. Polish Journal of Food and Nutrition Sciences, 62(4), 241-250. doi: 10.2478/v10222-012-0060-x.

Ismail, M., Ali, S., \& Hussain, M. (2014). Quantitative Determination of Ascorbic Acid in Commercial Fruit Juices by Redox Titration. International Journal of Pharmaceutical Quality Assurance. 5(4); 22-25.

Jaramillo, A. M., Londoño, L. F., Orozco, J. C., Patiño, G., Belalcazar, J., Davrieux, F., Talsma, E. F. (2018). A comparison study of five different methods to measure carotenoids in biofortified yellow cassava (Manihot esculenta). Plos One, 28,

https://doi.org/10.1371/journal.pone.020970 2.

Jirapa, K., Jarae, Y., Phanee, R., \& Jirasak, K. (2016). Changes of bioactive components in germinated paddy rice (Oryza sativa L.). International Food Research Journal, 23(1), 229-236.

Kumar, V., Ahluwalia, V., Saran, S., Kumar, J., Patel, A. K., Singhania, R. R. (2021). Recent developments on solid-state fermentation for production of microbial secondary metabolites: challenges and solutions, Bioresource Technology, 323, 124566.

Leite, P., Silva, C., Salgado, J. M., \& Belo, I. (2019). Simultaneous production of lignocellulolytic enzymes and extraction of antioxidant compounds by solid-state fermentation of agroindustrial wastes. Industrial Crops and Products, 137, 315-322. doi: 10.1016/ j.indcrop.2019.04.044.
Liu, Y., Duan, X., Zhang, M., Li, C., Zhang, Z., Liu, A., Hu, B., He, J., Wu, D., Chen, H., \& Wu, W. (2020). Cooking methods effect on the nutrients, bioaccessibility and antioxidant activity of Craterellus cornucopioides. LWT, 131, $109768 . \quad$ doi: 10.1016/j.Iwt.2020.109768.

Megat, R. M. R., Azrina, A., \& Norhaizan, M. E. (2016). Effect of germination on total dietary fibre and total sugar in selected legumes. International Food Research Journal, 23(1), 257-261.

Metsa"muuronen, S. \& Sire'n, H. (2019). Bioactive phenolic compounds, metabolism and properties: a review on valuable chemical compounds in Scots pine and Norway spruce. Phytochemistry Reviews, 18:623-664. https://doi.org/10.1007/s11101-019-096302.

Murphy, P.A. (1982). Phytoestrogen content of processed soybean product. Food Technology, $36,60-64$.

Nazarni, R., Purnama, D., Umar, S., \& Eni, H. (2016). The effect of fermentation on total phenolic, flavonoid and tannin content and its relation to antibacterial activity in jaruk tigarun (Crataeva nurvala, Buch HAM). International Food Research Journal, 23(1), 309-315.

Oliveira, M. S., Cipolatti, E. P., Furlong, E. B., \& Soares, L. S. (2012). Phenolic compounds and antioxidant activity in fermented rice (Oryza sativa) bran. Ciência Tecnologia de Alimentos, Campinas, 32(3), 531-537. https://doi.org/10.1590/S0101 20612012005000071.

Phattayakorn, K., Pajanyor, P., Wongtecha, S., Prommakool, A., \& Saveboworn, W. (2016). Effect of germination on total phenolic content and antioxidant properties of 'Hang' rice. International Food Research Journal, 23(1), 406-409.

Rashad, M. M., Mahmoud, A. E., Abdou, H. M., \& Nooman, M. U. (2011). Improvement of nutritional quality and antioxidant activities of yeast fermented soybean curd residue. African Journal of Biotechnology, 10(28), 5504-5513. DOI: 10.5897/AJB10.1658.

Richard, D., Kefi, K., Barbe, U., Bausero, P., \& Visioli, F. (2008). Polyunsaturated fatty acids as antioxidants. Pharmacological Research, 57(6), 451-455.

Suryanti, V., Marliyana, S. D., \& Putri, H. E., (2016). Effect of germination on antioxidant activity, total phenolics, $\beta$-carotene, ascorbic acid and $\alpha$-tocopherol contents of lead tree sprouts (Leucaena leucocephala (Imk.) de Wit). International Food Research Journal, 23(1), 167-172. 
Suryanti, V., Kusumaningsih, T., Marliyana, S. D., Setyono, H. A., \& Trisnawati, E. W. (2020). Identification of active compounds and antioxidant activity of teak (Tectona grandis) leaves. Biodiversitas. 21 (3), 946-952.

Tzanova, M., Atanasov, V., Yaneva, Z., Ivanova, D., \& Dinev, T. (2020). Selectivity of current extraction techniques for flavonoids from plant materials. Processes, 8, 1222; doi:10.3390/pr8101222.

Verni, M., Verardo, V., \& Rizzello, C. G. (2019). How fermentation affects the antioxidant properties of cereals and legumes. Foods, 8(9), 362. doi: 10.3390/foods8090362.

Vital, R. J., Bassinello, P. Z., Cruz, Q. A., Carvalho, R. N., De Paiva, J., \& Colombo, A. O. (2018). Production, quality, and acceptance of tempeh and white bean tempeh burgers. Foods, 7(9),
136. doi: $10.3390 /$ foods7090136.

Zarina, Z., Ruzaidi, C. M., Sam, S. T., \& Al Bakri, A. M. M. (2019). Investigation on Antioxidants Compounds Composition Contains in Leucaena Leucocephala (Petai Belalang). IOP Conf. Series: Materials Science and Engineering, 551, 012016, doi:10.1088/1757-899X/551/1/012016.

Zia, S., Khan, M. R., Shabbir, M. A., Aslam Maan, A., Khan, M. K. I., Nadeem, M., Khalil, A. A., Din, A., \& Aadil, R. M. (2020). An inclusive overview of advanced thermal and nonthermal extraction techniques for bioactive compounds in food and food-related matrices. Food Reviews International, https://doi.org/10.1080/87559129.2020.177 2283. 